\title{
ASSESSMENT OF THE QUALITY OF MALT OBTAINED FROM SPRING MALTING BARLEY DELIVERED TO THE SAN FARMERS' COOPERATIVE IN 2018
}

\author{
Józef Gorzelany ${ }^{\mathrm{a}^{*}}$, Justyna Belcar ${ }^{\mathrm{b}}$, Natalia Matłok ${ }^{\mathrm{c}}$ \\ a Department of Food and Agriculture Production Engineering, University of Rzeszow, Poland \\ ORCID 0000-0002-1028-097X \\ b Spółdzielnia Rolników SAN, Łąka 598, 36-004 Łąka, Poland, \\ c Department of Food and Agriculture Production Engineering, University of Rzeszow, Poland \\ ORCID 0000-0003-3658-7176 \\ *Corresponding author: e-mail: gorzelan@ur.edu.pl
}

\begin{tabular}{|c|c|}
\hline ARTICLE INFO & ABSTRACT \\
\hline $\begin{array}{l}\text { Article history: } \\
\text { Received: July } 2019 \\
\text { Received in the revised form: } \\
\text { August } 2019 \\
\text { Accepted: September } 2019 \\
\end{array}$ & $\begin{array}{l}\text { The study assesses the quality of malt from spring malting barley grown } \\
\text { in the Podkarpackie Province, and delivered to the SAN Farmers' Co- } \\
\text { operative in } 2018 \text {. After the initial technological assessment in the la- } \\
\text { boratory of SAN, the grain was malted in the Department of Agricul- } \\
\text { tural and Food Production Engineering at the Institute of Agricultural }\end{array}$ \\
\hline $\begin{array}{l}\text { Key words: } \\
\text { malting barley, } \\
\text { malting defects, } \\
\text { malt, } \\
\text { extractivity, } \\
\text { diastatic power }\end{array}$ & $\begin{array}{l}\text { Sciences, Land Management and Environmental Protection of the Uni- } \\
\text { versity of Rzeszow. Moisture, protein content, runoff time, viscosity, } \\
\mathrm{pH} \text {, wort clarity, extract content and diastatic power were determined } \\
\text { in the tested malt, as well as wort obtained from it in the process of } \\
\text { mashing. The average parameters of protein content, extractivity of } \\
\text { malt ground into flour, of pH and the wort extract were normative, while } \\
\text { the other researched parameters did not meet high quality requirements. } \\
\text { A high loss of grain mass was noted during malting. After laboratory } \\
\text { tests of malt and wort, it was determined that part of the malting raw } \\
\text { material is of high malting quality and can be used without modification } \\
\text { in the brewhouse for the malting and mashing process. }\end{array}$ \\
\hline
\end{tabular}

\section{Introduction}

Spring barley (Hordeum vulgare L.) is increasingly an alternative to growing other cereals. Depending on the technological parameters, it can be used to produce groats, malt, or as a feed. According to the Central Statistical Office of Poland (GUS 2018), in 2017, 3,793,000 tonnes of barley were produced in Poland, of which 40,400,000 hectoliters of beer were obtained. The share of barley crops in the Podkarpackie Province was low, but it has been steadily increasing year by year.

The year 2018 was unfavorable for the vegetation of malting barley in the Podkarpackie Province. Low rainfall in April and May caused uneven germination and increased protein content in the grain. Pecio and Kubasik (2006) believe that the increase in protein content in dry grain matter is very strongly influenced by the sum of precipitation during germination and maturing of grain. Liszewski et al. (2012) and Błażewicz et al. (2011) report that adverse 
weather conditions during plant vegetation (mainly at the stage of heading and flowering) cause a reduction in yield per unit area and have a negative impact on the brewing quality of the raw material. Despite the adverse conditions, sowing the malting variety, and supplying it with $30-60 \mathrm{~kg} \cdot \mathrm{ha}^{-1}$ of nitrogen resulted in optimal quality of barley.

Schmitt et al. (2013), Farzaneh et al. (2017) and Kleinwachter M. et al. (2014) define malting as a process of controlled germination of barley caryopses in appropriate conditions by soaking them, stimulating enzymatic activity and partial growth of the cotyledon, and then subjecting them to drying and germination. The processes occurring during malting and wort extraction are mainly hydrolysis of starch, conducted by three hydrolytic enzymes: $\alpha$-amylase, $\beta$-amylase and $\alpha$-glucosidase. $A$-amylase is a liquefying enzyme, while $\beta$-amylase is a maltogenic starch saccharification enzyme. Starch conversion produces glucose and maltose, which are used by brewer's yeast during alcoholic fermentation (Strąk and Balcerek, 2016). The total activity of $\alpha$ - and $\beta$-amylase that hydrolyze barley starch is defined as diastatic power, which is one of the most important determinants of malt quality. Protein degradation by proteolytic enzymes is a complex process, still researched by scientists.

According to Błażewicz et al. (2010), malt extractivity (efficiency) is the percentage share of substances contained in malt, which passed from malt to wort as a result of the mashing process. It depends on the dose of nitrogen fertilizer, and the type of barley used. High quality of malt is impacted by the appropriate enzymatic activity, high extractivity and short malting time. In new malting barley varieties, growers strive to reduce the time of grain germination by intensifying the changes occurring during malting, while maintaining high quality of the malt.

The purpose of the paper was to conduct the laboratory malting process, and to determine the quality of malt obtained from the KWS Irina malting barley variety delivered to the SAN Farmers' Cooperative from the Podkarpackie Province, along with the possibility of its use in the production of Pilsen-type malts.

\section{Material and methods}

The tested material was Pilsen-type malt obtained from the KWS Irina malting barley variety, which was delivered to the SAN Farmers' Cooperative in Gluchów in 2018. The grain came from the Podkarpackie Province, in particular from the Rzeszów, Łańcut, Przeworsk and Przemyśl districts. Technological assessment of barley was carried out in the Cooperative's laboratory in Głuchów (Belcar et al., 2019), in accordance with the Polish Standard PN-R-74109: 1997. Cereal, Barley - for malting barley class I, and with the Polish Standard PN-R-74110: 1998. Cereal. Barley - research methods.

Further research was carried out in the laboratory of the Institute of Agricultural Sciences, Land Management and Environmental Protection of the University of Rzeszów. Representative samples of the raw material were purified with Vogel sieves on the SŻK Sadkiewicz mechanical sorter, collecting the fraction $>2.5 \mathrm{~mm}$ (10 samples of $100 \mathrm{~g}$ each) for testing. Next, the protein content (Nx6.25) and TGW were determined, based on which theoretical extractivity was calculated using the Bishop's formula $\left(\mathrm{E}_{\mathrm{EBC}}=84.5-4,5 \mathrm{~N}+0.1 \mathrm{C}\right)$. The raw material was spread on metal germination plates covered with filter paper, and soaked for germination by spraying tap water from an atomizer at $20^{\circ} \mathrm{C}$ twice a day, at 12 -hour intervals (the Aubry method), in a climate cabinet, at $90 \%$ relative humidity and $20^{\circ} \mathrm{C}$ for 72 hours. 
Assessment of the quality of malt...

Afterwards, the raw material was dried in a laboratory dryer for the following time: $15 \mathrm{~h}-40^{\circ} \mathrm{C}, 3 \mathrm{~h}-50^{\circ} \mathrm{C}, 3 \mathrm{~h}-65^{\circ} \mathrm{C}$ and $2 \mathrm{~h}-82^{\circ} \mathrm{C}$, and then germinated.

In the obtained malt, the protein content (Nx6.25) was examined by spectrometry using an OmegAnalyzerGrain analyzer. Afterwards, the samples were subjected to grinding $(2 \mathrm{~mm})$ in a Cemotec disc mill from FOSS. In the tests, the moisture content was determined by the weight loss method after drying (according to PN-A-79083-5), followed by a mashing process according to 4.5.1 (Analytica EBC, 2004).

In the laboratory wort, obtained as a result of mashing, the content of the extract was determined in dry matter of malt ground into flour, as well as its clarity and runoff time (all analyzes in accordance with PN-A-79083-6). The viscosity of the laboratory wort was determined in accordance with PN-A-79083-7, calculated per conventional wort, $8.6 \%$ by weight, using a Höppler viscometer. The $\mathrm{pH}$ of the laboratory wort was determined by the potentiometric method (PN-A-79083-12), while the diastatic power of malt by the titration (iodine) method, according to PN-A-79083-10.

Natural defects occurring during malting were calculated by determining the mass of 1000 grains before and after the malting process. The dry masses of grain and malt were expressed as a percentage weight loss in 1000 grains.

All the described analyzes were carried out in two parallel replicates. The results were developed using the Statistica 13.3 statistical program. To interpret the results, Pearson's linear correlation coefficients were used, at a significance level $\alpha=0.05$, to determine the relationship between the selected malting process features, and between individual quality components of malt and wort.

\section{Results and discussion}

In 2018, approximately 3.000 tons of spring barley were delivered to the laboratory of the SAN Farmers' Cooperative in Głuchów, and 290 analyzes of the malting raw material were performed. The average technological parameters of malting barley grain were characterized by a high content of total impurities (mainly dehusked grain, halves and fraction $<2.2 \mathrm{~mm}$ ), increased protein content and reduced grain uniformity. The conducted tests of energy and germination ability of malting barley grain confirmed the reduction of these parameters, as compared to the norm for the brewing raw material. In each batch of raw material, individual grains infected with fungi of the genus Fusarium could be observed (Belcar et al. 2019).

After accepting the barley into the warehouse in Głuchów, 10 representative samples were taken from the batch. They were then cleaned and the fraction $>2.5 \mathrm{~mm}$ was selected, to be subjected to the malting process.

Barley grains subjected to the malting process were highly diversified: some of the grains were properly husked, a very large number of grains had only part of the husk, and some were completely naked. Such a diversity of the malting raw material was caused by the threshing process in harvesters, which caused mechanical damage to the grain during harvest (Belcar et al., 2019). The malting process was carried out within 3 days. Lack of full grain husk caused uneven water absorption by the caryopses and the varying final moisture content of the raw material (from $45.3 \%$ to as much as $65.9 \%$, Table 1). Too high humidity of the grain during malting (the method selected) could cause damage, and consequently, dying of the embryos. 
Józef Gorzelany, Justyna Belcar, Natalia Matłok

Table 1.

Protein content in barley grain and the effect of malting on the weight of 1000 grains, as well as moisture and natural defects of malt

\begin{tabular}{|c|c|c|c|c|c|c|c|c|}
\hline No. & $\begin{array}{c}\text { Protein } \\
\text { content in } \\
\text { barley } \\
(\% \mathrm{DM})\end{array}$ & $\begin{array}{l}\text { Average } \\
\text { TGW for } \\
\text { barley } \\
\text { (g DM) }\end{array}$ & $\begin{array}{c}\text { Average } \\
\text { TGW for } \\
\text { malt } \\
\text { (g DM) }\end{array}$ & $\begin{array}{c}\text { Total } \\
\text { weight loss } \\
(\% \mathrm{DM})\end{array}$ & $\begin{array}{l}\text { Weight } \\
\text { loss in } \\
\text { germs } \\
(\% \text { DM) }\end{array}$ & $\begin{array}{l}\text { Weight } \\
\text { loss in } \\
\text { grain } \\
(\% \text { DM })\end{array}$ & $\begin{array}{c}\text { Initial } \\
\text { humidity } \\
(\%)\end{array}$ & $\begin{array}{l}\text { Moisture } \\
\text { after } \\
\text { drying } \\
(\%)\end{array}$ \\
\hline 1. & 11.60 & 41.06 & 38.81 & 11.03 & 1.72 & 9.23 & 46.40 & 9.10 \\
\hline 2. & 11.60 & 41.64 & 37.81 & 15.03 & 1.94 & 13.09 & 47.30 & 7.33 \\
\hline 3. & 12.20 & 41.78 & 38.21 & 11.86 & 2.86 & 9.02 & 48.00 & 9.01 \\
\hline 4. & 12.10 & 43.06 & 41.36 & 8.26 & 4.90 & 3.35 & 54.10 & 6.63 \\
\hline 5. & 11.10 & 43.70 & 38.81 & 17.82 & 3.40 & 14.42 & 45.47 & 3.94 \\
\hline 6. & 11.50 & 42.64 & 39.76 & 12.33 & 4.72 & 7.61 & 56.44 & 5.78 \\
\hline 7. & 11.30 & 42.94 & 38.32 & 13.70 & 4.28 & 9.81 & 65.90 & 9.20 \\
\hline 8. & 12.00 & 43.16 & 39.43 & 12.03 & 3.88 & 7.15 & 48.50 & 7.65 \\
\hline 9. & 12.00 & 43.76 & 40.34 & 10.25 & 2.92 & 7.33 & 51.60 & 9.54 \\
\hline 10. & 10.20 & 39.52 & 36.04 & 13.89 & 3.27 & 10.62 & 45.30 & 7.59 \\
\hline $\begin{array}{l}\text { Mean } \\
\text { and } \\
\text { stand- } \\
\text { ard de- } \\
\text { viation }\end{array}$ & $11.56 \pm 0.59$ & $42.33 \pm 1.33$ & $38.89 \pm 1.46$ & $12.62 \pm 2.66$ & $3.39 \pm 1.08$ & $9.16 \pm 3.15$ & $50.90 \pm 6.4$ & $7.57 \pm 1.77$ \\
\hline
\end{tabular}

In studies conducted by Błażewicz et al. (2010) the final humidity result of approx. $45 \%$ was obtained by controlling the degree of soaking the grain during the process of soaking. At such diversified final moisture content, the drying program used for the malted grains did not fulfill its role - the malt was insufficiently dried. The average humidity after drying was 7.57 $\pm 1.77 \%$, as compared to the malt storage standard, which is up to $4.5 \%$ [PN- A-79082]. Malt with high humidity should be used immediately for beer production as it cannot be aged for long (provided other quality parameters are high).

For barley, the average mass of 1000 grains was $42.33 \pm 1.33 \mathrm{~g}$, and for malt obtained from it, $38.89 \pm 1.46 \mathrm{~g}$ (Table 1). Both before and after the malting process, the examined parameter was within the norm, which for barley is 35-45 g, and for malt: 30-40 g (Haberowa and Raczyńska-Cabaj, 2004). The average natural defects occurring during malting were $12.62 \pm 2.66 \%$ DM (Table 1), including the average germ loss of $26.9 \%$ of the total weight loss, while the weight loss due to changes in the caryopses was $72.60 \%$. In their research, Błażewicz et al. (2010) obtained an average total weight loss of $8.30 \%$ DM for 3-day malts. The same research team reported that the total weight loss during malting should range between 12 and 14\%, the weight loss in germs, 3-4\%, and the weight loss of the caryopse, $4-8 \%$. In the conducted tests, an increased weight loss of the caryopse $(9.16 \pm 3.15 \% \mathrm{DM})$ was obtained, which impacted the results of the performed malt and wort analyzes. On the other hand, the weight loss in germs $(3.39 \pm 1.08 \% \mathrm{DM})$ and the total weight loss in the malting process was normative. 
Assessment of the quality of malt...

Table 2.

Results of correlation coefficients for the studied variables of the malting process at a significance level of $p<0.05$

\begin{tabular}{|c|c|c|c|c|c|c|c|c|}
\hline Variable & $\begin{array}{l}\text { Protein } \\
\text { content in } \\
\text { barley }\end{array}$ & $\begin{array}{c}\text { Average } \\
\text { TGW for } \\
\text { barley }\end{array}$ & $\begin{array}{c}\text { Average } \\
\text { TGW for } \\
\text { malt }\end{array}$ & $\begin{array}{c}\text { Total } \\
\text { weight } \\
\text { loss }\end{array}$ & $\begin{array}{l}\text { Weight } \\
\text { loss in } \\
\text { germs }\end{array}$ & $\begin{array}{l}\text { Weight } \\
\text { loss in } \\
\text { grain }\end{array}$ & $\begin{array}{c}\text { Initial } \\
\text { humidity }\end{array}$ & $\begin{array}{c}\text { Moisture } \\
\text { after } \\
\text { drying }\end{array}$ \\
\hline $\begin{array}{l}\text { Protein in } \\
\text { barley } \\
\text { Average }\end{array}$ & 1.000000 & 0.554839 & 0.726472 & -0.592217 & 0.035700 & -0.544621 & 0.134700 & 0.282112 \\
\hline $\begin{array}{l}\text { TGW for } \\
\text { barley }\end{array}$ & 0.554839 & 1.000000 & 0.762237 & -0.067918 & 0.430228 & -0.218502 & 0.392637 & -0.233995 \\
\hline $\begin{array}{l}\text { Average } \\
\text { TGW for } \\
\text { malt }\end{array}$ & 0.726472 & 0.762237 & 1.000000 & -0.608862 & 0.446800 & -0.687097 & 0.311397 & -0.107640 \\
\hline $\begin{array}{l}\text { Total } \\
\text { weight } \\
\text { loss }\end{array}$ & -0.592217 & -0.067918 & -0.608862 & 1.000000 & -0.221134 & 0.936763 & -0.221655 & -0.501343 \\
\hline $\begin{array}{l}\text { Weight } \\
\text { loss in } \\
\text { germs }\end{array}$ & 0.035700 & 0.430228 & 0.446800 & -0.221134 & 1.000000 & -0.530970 & 0.621103 & -0.362597 \\
\hline $\begin{array}{l}\text { Weight } \\
\text { loss in } \\
\text { grain }\end{array}$ & -0.544621 & -0.218502 & -0.687097 & 0.936763 & -0.530970 & 1.000000 & -0.353743 & -0.290086 \\
\hline $\begin{array}{l}\text { Initial } \\
\text { humidity }\end{array}$ & 0.134700 & 0.392637 & 0.311397 & -0.221655 & 0.621103 & -0.353743 & 1.000000 & 0.214840 \\
\hline $\begin{array}{l}\text { Moisture } \\
\text { after } \\
\text { drying }\end{array}$ & 0.282112 & -0.233995 & -0.107640 & -0.501343 & -0.362597 & -0.290086 & 0.214840 & 1.000000 \\
\hline
\end{tabular}

The calculated Pearson linear correlation coefficients (Table 2) indicate a very high, statistically significant and proportional relationship between total weight loss and the weight loss of the caryopse. The higher their weight loss, the higher the total weight loss. The weight loss of grain is characterized by a high inversely proportional relationship to that of TGW of malt. This means that the higher the TGW of malt grains, the lower the weight loss of caryopses. However, the content of protein and TGW of malting barley grain is very high, positively correlated with the TGW of malt. The higher the protein content in barley grain, the higher the TGW of barley grains, which after the malting process gives a higher TGW of malt grains. Other examined features of the malting process are moderately correlated, and these correlations were not statistically significant. The results of the analyzes carried out for barley malt are summarized in Table 3. 
Józef Gorzelany, Justyna Belcar, Natalia Matłok

Table 3.

The results of qualitative distinguishing features for malt and laboratory wort samples

\begin{tabular}{|c|c|c|c|c|c|c|c|c|c|}
\hline$\dot{\mathbf{z}}$ & 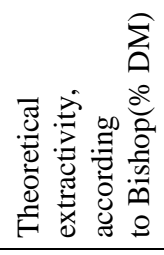 & 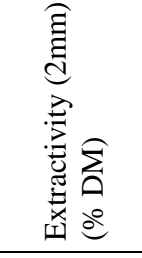 & 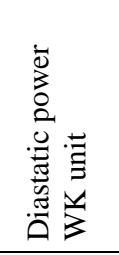 & 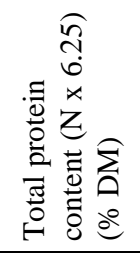 & $\stackrel{\overparen{\Xi}}{\stackrel{\Xi}{U}}$ & 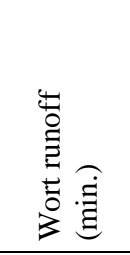 & I & 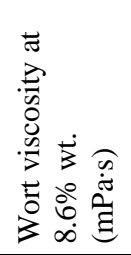 & 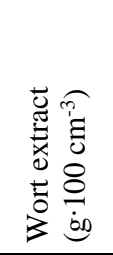 \\
\hline 1. & 80.10 & 90.94 & 243 & 11.2 & $\begin{array}{l}\text { Slightly } \\
\text { opales- } \\
\text { cent }\end{array}$ & 90 & 5.30 & 2.07 & 9.60 \\
\hline 2. & 76.15 & 84.89 & 244 & 11.3 & $\begin{array}{l}\text { Slightly } \\
\text { opales- } \\
\text { cent }\end{array}$ & 90 & 5.30 & 1.65 & 9.34 \\
\hline 3. & 75.72 & 81.85 & 261 & 11.8 & Clear & 60 & 5.27 & 1.83 & 9.60 \\
\hline 4. & 75.79 & 75.75 & 253 & 11.3 & Clear & 60 & 5.45 & 1.96 & 9.34 \\
\hline 5. & 76.51 & 80.75 & 212 & 10.2 & Clear & 60 & 5.35 & 1.62 & 9.09 \\
\hline 6. & 76.22 & 77.39 & 243 & 10.4 & Clear & 60 & 5.37 & 2.21 & 9.60 \\
\hline 7. & 76.36 & 82.28 & 203 & 10.6 & Clear & 60 & 5.50 & 1.81 & 9.17 \\
\hline 8. & 75.86 & 81.82 & 268 & 11.3 & Clear & 60 & 5.35 & 1.62 & 9.45 \\
\hline 9. & 75.86 & 81.44 & 229 & 10.9 & Clear & 60 & 5.83 & 1.32 & 9.60 \\
\hline 10. & 77.16 & 84.41 & 205 & 9.7 & Clear & 60 & 5.88 & 1.48 & 9.34 \\
\hline $\begin{array}{l}\text { Mean } \\
\text { and } \\
\text { stand- } \\
\text { ard de- } \\
\text { viation }\end{array}$ & $76.57 \pm 1.31$ & $81.15 \pm 2.8$ & $236.1 \pm 23$ & $10.87 \pm 0.6$ & - & $66 \pm 12.46$ & $5.46 \pm 0.2$ & $1.76 \pm 0.3$ & $9.41 \pm 0.2$ \\
\hline
\end{tabular}

From among all factors characterizing Pilsner type malt, total protein content, extractivity, wort extract, diastatic power, $\mathrm{pH}$, wort clarity and viscosity are determined. In malted grain, the normative protein content is up to $11.3 \%$. Błażewicz et al. (2013) report that protein content variation in malt is influenced by the soaking time, uneven germination of the grain (which was observed during the process) and increased protein content in barley, which is intended for the malting process. The total protein content $(\mathrm{N} \times 6.25)$ in the tested samples was $90 \%$ normative and averaged $10.87 \pm 0.6 \%$. The malting raw material's average protein content was $11.56 \pm 0.59 \%$, and was slightly increased compared to the standard, which is max. $11.5 \%$. During malting, an increased loss of protein content in caryopses was also observed, ranging from $0.3 \%$ to as much as $1.1 \%$, which was caused by uneven grain germination, and conducting the germination process at $20^{\circ} \mathrm{C}$. Schmitt et al. (2013) attribute a large loss of protein during malting to the development of roots and shoots of a new plant. Kunze (2010) determines good quality malt as that with up to $10.8 \%$ protein content, with a protein loss of not more than $0.5 \%$, in relation to its amount in barley grain. According to Błażewicz et al. (2013), increased protein content in barley impacts its reduced extractivity and increased enzymatic activity. This has not been confirmed in this study, because the average extractivity is high, while the Windlisch-Kolbach index, determining the activity of $\alpha$ - and $\beta$-amylases is relatively low. 
Malt extractivity is the basic and most important parameter for breweries as it determines the amount of substances that pass from malt to wort. It is on this basis that the amount of charge and the yield of a given batch of the produced beer are calculated. In the performed tests, malt extractivity was above $80 \%$ DM for eight results. Błażewicz et al. (2010) state that the extractability of malt depends on the protein content in the grain used for malting. The results of the theoretical and obtained extractivity differ by approximately 5 percentage points. The average extractability calculated from the Bishop's formula is $76.57 \pm 1.31 \%$, while the average extractability of malt milled into flour is $81.15 \pm 2.8 \%$. According to Błażewicz et al. (2007), theoretical extractivity allows to assess its suitability for the production of Pilsen type malts already at the stage of purchasing the raw material. Liszewski et al. (2012) report that the theoretical extractivity decreases along with the increasing protein content in barley grain. The claims of both research teams have been confirmed in the test results presented above. However, the difference in theoretical and practical extractivity demonstrated that at increased protein content in barley grain, and lower (but normal) TGW, calculating extractivity according to Bishop yields underestimated results, as compared to the results of laboratory tests.

The diastatic power of malt determines the activity of malt amylolytic enzymes, which break down starch into sugars, processed into ethyl alcohol by yeasts during fermentation. The activity of the enzymes is expressed in Windlisch-Kolbach (WK) units, and for Pilsen type malts it can't be lower than $240 \mathrm{WK}$. Worts with below normal diastatic power contain partially non-hydrolyzed starch, and the beers obtained from them are characterized by a low degree of final fermentation (Kunze, 2010). In the conducted tests, diastatic power of $40 \%$ of the samples was lower than $240 \mathrm{WK}$, and the average diastatic power in the tested samples was $236.1 \pm 23 \mathrm{WK}$. The possibility of weakening the enzymatic potential of malt during malting was probably due to the uneven uptake of water of the grain, and excessive moisture of the soaked grain. Zarnkow (2007) reports that the enzymatic activity of $\beta$-amylase, which cleaves glycosidic bonds and releases fermentable sugars, is affected by an increase in the temperature of mashing, up to the starch gelatinization level $\left(64.5^{\circ} \mathrm{C}\right)$. At this temperature, slow inactivation of the $\beta$-amylase enzyme begins.

The activity and efficiency of amylolytic and cytolytic enzymes in malt can be determined by examining wort viscosity. For high-quality (standard) malts, the viscosity should not exceed $1.67 \mathrm{mPa} \cdot \mathrm{s}$. In the results obtained, only $40 \%$ of the samples met the given range of values. The viscosity parameter depends not only on the amount of $\beta$-glucan (its soluble forms) in the wort, but also on the content of arabinoxylans that form aggregates, especially in the presence of $\beta$-glucans (Kasztelanowicz and Boros, 2005). During mashing, some of the arabinoxylans undergo partial degradation. They pass into the filtered wort causing an increase in viscosity of the tested samples. Increasing the viscosity in the wort causes problems during filtration, extending the filtration time and encouraging precipitation during aging and maturation of beer.

The wort runoff time was the time required for the wort to pass completely through the filter septum. Runoff within 1 hour is defined as "normal" and above that time was marked as "slow". In the tested malt samples, $80 \%$ of the wort was filtered within 1 hour, while two samples were filtered for 90 minutes. The runoff time is positively correlated with the viscosity parameter. The more compounds that increase the viscosity ( $\beta$-glucans, arabinoxylans, other polysaccharides), the longer the runoff time, because they hinder the flow of wort through the filtration barrier. Two slightly opalescent worts were obtained. 
Józef Gorzelany, Justyna Belcar, Natalia Matłok

The optimal activity of enzymes that break down substances in malt during mashing depends on its $\mathrm{pH}$. The $\mathrm{pH}$ of the obtained worts ranged from 5.27 to 5.88. During the tests, two samples of wort had a pH higher than 5.8. The Polish Norm determining the $\mathrm{pH}$ requirements for class I wort obtained from Pilsner malt states that the $\mathrm{pH}$ must not be higher than 5.9. Nowak et al. (2009) recommend lowering the $\mathrm{pH}$ of the wort obtained from malt and water to 5.2-5.3 due to the reduction of proteolytic enzyme activity, and the resulting insufficient protein degradation and increased wort viscosity, at $\mathrm{pH}$ above 5.6. Zarnkow (2007) stated that the optimal $\mathrm{pH}$ for $\beta$-amylase activity is 5.7 , and combined with an appropriate mash temperature range, it leads to high mashing efficiency. No mash $\mathrm{pH}$ correction is expected in the laboratory congress mashing method of Pilsen type malt.

Table 4.

Results of correlation coefficients for the studied variables of malt and wort at a significance level of $p<0.05$

\begin{tabular}{lccccccccc}
\hline Variable & $\begin{array}{c}\text { Theoreti- } \\
\text { cal ex- } \\
\text { tractivity }\end{array}$ & $\begin{array}{c}\text { Extra- } \\
\text { ctivity }\end{array}$ & $\begin{array}{c}\text { Diastatic } \\
\text { power }\end{array}$ & $\begin{array}{c}\text { Protein } \\
\text { content }\end{array}$ & $\begin{array}{c}\text { Runoff } \\
\text { time }\end{array}$ & $\mathrm{pH}$ & $\begin{array}{c}\text { Wort vis- } \\
\text { cosity }\end{array}$ & $\begin{array}{c}\text { Wort ex- } \\
\text { tract }\end{array}$ \\
\hline $\begin{array}{l}\text { Theoretical } \\
\text { extractivity }\end{array}$ & 1.000000 & 0.110481 & -0.159127 & -0.119437 & 0.623407 & -0.090713 & 0.314302 & 0.175701 \\
$\begin{array}{l}\text { Extractivity } \\
\text { Diastatic }\end{array}$ & 0.110481 & 1.000000 & -0.313029 & -0.119872 & 0.332188 & 0.214497 & -0.614909 & -0.167246 \\
power & -0.159127 & -0.313029 & 1.000000 & 0.817800 & 0.169324 & -0.565482 & 0.328740 & 0.597473 \\
$\begin{array}{l}\text { Protein } \\
\text { content }\end{array}$ & -0.119437 & -0.119872 & 0.817800 & 1.000000 & 0.314879 & -0.576345 & 0.210832 & 0.438619 \\
$\begin{array}{l}\text { Runoff time } \\
\text { pH }\end{array}$ & 0.623407 & 0.332188 & 0.169324 & 0.314879 & 1.000000 & -0.383747 & 0.199079 & 0.159168 \\
Wort vis- & -0.090713 & 0.214497 & -0.565482 & -0.576345 & -0.383747 & 1.000000 & -0.621924 & -0.025718 \\
$\begin{array}{l}\text { cosity } \\
\text { Wort extract }\end{array}$ & 0.17574302 & -0.614909 & 0.328740 & 0.210832 & 0.199079 & -0.621924 & 1.000000 & 0.247603 \\
\hline & -0.167246 & 0.597473 & 0.438619 & 0.159168 & -0.025718 & 0.247603 & 1.000000 \\
\hline
\end{tabular}

The calculated Pearson linear correlation coefficients (Table 4) indicate a high, statistically significant relationship between diastatic power and protein content. These are proportional relationships, which means that the higher the protein content in malt, the higher their diastatic power. Malt extractivity is highly and negatively correlated with wort viscosity, which means that the higher the viscosity, the more difficult the passage of products of malt ingredients' enzymatic hydrolysis into the wort. Wort extract is positively, highly correlated with diastatic power, because the amount of substances that have passed into the wort depends on the activity of enzymes. Other examined features of malt and wort are moderately correlated, and these correlations were not statistically significant.

After testing barley, malt and wort on a laboratory scale, it was found that in industrial conditions, the process of malting barley should be modified. Extended germination time at a temperature of the malting process of barley reduced from $20^{\circ} \mathrm{C}$ to a dozen or so degrees would positively impact the enzymatic activity of malt and its diastatic power, and would reduce the viscosity by potentiating $\beta$-glucanase, with a likely reduction in malting efficiency (Farzeneh et al. 2017). Błażewicz et al. (2010) report that the malting process can be intensified with certain plant hormones, enzymes or preparations containing gibberellic acid. This reduces germination time and increases the intensity of changes occurring in the caryopses, 
Assessment of the quality of malt...

and thus increases the economic efficiency of the malt house. A very important step impacting the quality of malt and wort is choosing the right malting barley variety and vegetation conditions. According to Liszewski et al., an increased dose of nitrogen fertilizers (2012) causes not only an increase in the amount of protein in barley grain, but also reduces malt extractivity.

\section{Conclusions}

1. After laboratory tests of malt and wort, it was determined that part of the malting raw material is of high malting quality and can be used without modification in the brewhouse for the malting and mashing process.

2. The inability to separate parts of high-quality raw material from that of reduced parameters (e.g. with a damaged husk) significantly deteriorates the malting process and reduces the quality of Pilsen type malt.

3. During the malting process, an excessive weight loss of grain was found, caused by an increased intake of the storage substance by the germinating barley grain malted at $20^{\circ} \mathrm{C}$, which accelerated the metabolism of grain and malt.

\section{References}

Analytica-EBC (2004). Method 4.5.1 Extract of Malt: Congress Mash. Hans Carl Getränke-Fachverlag, Nürnberg.

Belcar, J., Gorzelany, J., Matłok, N. (2019). Ocena właściwości technologicznych jęczmienia browarnego z terenu województwa podkarpackiego dostarczanego do Spółdzielni Rolników SAN w Gtuchowie. [in:] Rolnictwo XXI wieku - problemy i wyzwania 2019 (red. D. Łuczycka), Idea Knowledge Future, Wrocław, 33-45.

Błażewicz, J., Liszewski, M., Zembold-Guła, A., Kozłowska, K., Szwed, Ł. (2013). Liczba Kolbacha jako ważny wskaźnik wartości przetwórczej ziarna jęczmienia browarnego. Fragmenta Agronomica, 30(3), 46-53.

Błażewicz, J., Zembold-Guła, A., Żarski, J., Dudek, S., Kuśmierek-Tomaszewska, R. (2011). Wpływ deszczowania i nawożenia azotem $w$ technologii uprawy jęczmienia browarnego na wydajność procesu stodowania - wstępne wyniki badań. Infrastruktura i Ekologia Terenów Wiejskich, 6, Kraków, 109-117.

Błażewicz, J., Zembold-Guła, A., Szwed, Ł., Liszewski, M. (2010). Wpływ nawożenia azotem jęczmienia oraz czasu kiełkowania ziarna na wielkość ubytków naturalnych procesu słodowania. Pamiętnik Pulawski, 152, 29-39.

Błażewicz, J., Liszewski, M., Zembold-Guła, A. (2007). Usability of Bishop formula in evaluation of malting quality of barley grain. Polish Journal of Food and Nutrition Sciences, 57, 4(A) 37-40.

Farzaneh, V., Ghodsvali, A., Bakhshabadi, H., Zane, Z., Carvalho, I. (2017). The impact of germination time on the some selected parameters through malting process. International Journal of Biological Macromolecules, 94 , pp. 663-668.

Gołębiewski, D., Myszka, K., Fraś, A. Boros, D., Burek, J., Mańkowski, D. (2013). Ocena zróżnicowania genotypowego i środowiskowego cech wartości browarnej rodów jęczmienia jarego z doświadczeń przedrejestrowych z roku 2012. Biuletyn Instytutu Hodowli i Aklimatyzacji Roślin, 268, $47-58$.

Central Statistical Office of Poland (GUS) 2018. Statistical Yearbook of Agriculture, pp. 147-150.

Haberowa, H., Raczyńska-Cabaj, A. (2004). Towaroznawcza i technologiczna ocena jęczmienia $i$ stodu. Wydawnictwo SGGW. ISBN 9788372445265. 
Kasztelowicz, K., Boros, D. (2005). Wstępne badania nad zastosowaniem testu lepkości jako prostego kryterium selekcji jakościowej jęczmienia browarnego i pastewnego. Biuletyn Instytutu Hodowli $i$ Aklimatyzacji Roślin, 235, 147-154.

Kleinwachter, M., Muller, Ch., Methner, F. J., Selmar, D. (2014). Biochemical heterogeneity of Malt is caused by both biological variation and differences in processing: Individual grain analyses of biochemical parameters in differently steeped barley (Hordeum vulgare L.) malts. Food Chemistry, 147, 25-33.

Kunze, W. (2010). Technology Brewing and Malting. $4^{\text {th }}$ updated edition. VLB Berlin. ISBN 978-3921690-64-2.

Liszewski, M., Błażewicz, J., Zembold-Guła, A., Szwed, Ł., Kozłowska, K. (2012). Wpływ sposobu nawożenia azotem na ekstraktywność słodu jęczmiennego. Fragmenta Agronomica, 29(1), 93-104.

Nowak, J., Paluszkiewicz, M., Lasik, M. (2009). Wpływ pH zacieru i brzeczki na przebieg procesu technologicznego i wybrane wyróżniki jakościowe piwa. Bromat. Chem. Toksykol. XLII, 3, 414419.

Pecio, A., Kubasik, K. (2006). Zróżnicowanie plonu i zawartości białka w ziarnie jęczmienia jarego w obrębie pola produkcyjnego. Pamiętnik Puławski, 142, 349-362.

PN - R- 74109: 1997 and PN - R- 74110: 1998 regarding the assessment of barley grain.

PN-A-79082: 1997, PN-A-79083-5: 1998, PN-A-79083-6: 1998, PN-A-79083-7: 1998, PN-A-7908310: 1998, PN- A-79083-12: 1998 regarding the assessment of barley malt.

Schmitt, M., Skadsen, R., Budde, A. (2013). Protein mobilization and malting - specific proteinase expression during barley getermination. Journal of Cereal Science, 58, 324-332.

Strąk, E., Balcerek, M. (2016). Słody jako źródło enzymów amylolitycznych w procesie enzymatycznej hydrolizy skrobi. ŻYWNOŚĆ. Nauka. Technologia. Jakość, 6(109), 41-54.

Zarnkow, M. (2007). Wpływ temperatury kleikowania słodu jęczmiennego na proces zacierania. Agro Przemyst, 6, 33-36.

Zembold, A., Błażewicz, J. (2006). Ziarno jęczmienia nagiego i oplewionego jako surowiec niesłodowany w piwowarstwie. ŻYWNOŚĆ. Nauka. Technologia. Jakość. 3(48), 35-50.

\title{
OCENA JAKOŚCI SLODU OTRZYMANEGO Z ZIARNA JAREGO JECZMIENIA BROWARNEGO DOSTARCZONEGO DO SPÓŁDZIELNI ROLNIKÓW SAN W ROKU 2018
}

\begin{abstract}
Streszczenie. W pracy dokonano oceny jakości słodu z jarego jęczmienia browarnego z województwa podkarpackiego dostarczonego do Spółdzielni Rolników SAN w roku 2018. Po wstępnej ocenie technologicznej w laboratorium SR SAN ziarno poddano procesowi słodowania w Katedrze Inżynierii Produkcji Rolno - Spożywczej na Wydziale Biologiczno-Rolniczym UR. W badanym słodzie i uzyskanej z niego w wyniku zacierania brzeczki określono wilgotność, zawartość białka, czas spływu, lepkość, pH i klarowność brzeczki, zawartość ekstraktu i siłę diastatyczną. Średnie parametry zawartości białka, ekstraktywności słodu zmielonego na mąkę, pH i ekstraktu brzeczki były normatywne, natomiast pozostałe badane parametry nie spełniły wysokich wymagań jakościowych. W czasie słodowania uzyskano wysoki ubytek masy ziarna po procesie. Po przeprowadzeniu badań laboratoryjnych słodu i brzeczki określono, że część surowca browarniczego posiada wysoką jakość słodowniczą i może być wykorzystana bez modyfikacji do procesu słodowania i zacierania w warzelni.
\end{abstract}

Słowa kluczowe: jęczmień browarny, ubytki słodowania, słód, ekstraktywność, siła diastatyczna 